\title{
DARI PRASANGKA HINGGA DISKRIMINASI: MENYOAL STIGMA SESAT DAN KEKERASAN TERHADAP AHMADIYAH DALAM PERSPEKTIF KOMUNIKASI
}

\author{
Halimatusa'diah \\ Pusat Penelitian Kemasyarakatan dan Kebudayaan \\ Lembaga Ilmu Pengetahuan Indonesia \\ halimatusadiah8015@gmail.com
}

\begin{abstract}
Ahmadiyya as a minor belief is not a new community in Indonesia. Since reformation era, their existence experiences controversies as well as oppositions from the society. From desk research and literature review method, this paper aims to describe the ways prejudice toward Ahmadiyy community emerge and draw the role of communication in connecting the major and minor community in Indonesia. This paper discusses the violence against the Ahmadiyya in Indonesia through communication perspective. The concept of prejudice expression from GW Allport (1954) and Samovar (2013) in this paper shows that violence experienced by Ahmadiyya is already at the stage of extermination rather than only at discrimination stage.
\end{abstract}

Keywords: prejudice, discrimination, intercommunity communication, deviant stigma, Ahmadiyya.

\begin{abstract}
ABSTRAK
Ahmadiyah di Indonesia, bukanlah kelompok minoritas keagamaan yang baru. Sejak era reformasi, keberadaan mereka mulai mendapat perlawanan dari masyarakat luas. Diskriminasi dan kekerasan terhadap kelompok ini meningkat tajam. Dengan menggunakan metode studi dokumen, tulisan ini bertujuan untuk menjelaskan proses munculnya prasangka pada kelompok minoritas Ahmadiyah dan menunjukkan peran komunikasi dalam menjembatani hubungan antarkelompok mayoritas dan minoritas di Indonesia. Ekspresi prasangka yang berpangkal dari konsep GW Allport (1954) dan dikembangkan oleh Samovar (2013) digunakan sebagai kerangka konseptual. Tulisan ini menemukan bahwa Ahmadiyah di Indonesia dewasa ini, tidak lagi berada dalam tahap terdiskriminasi, namun telah melampui tahap itu, yakni tahap extermination. Berbagai kasus kekerasan yang menimpa kelompok tersebut justru menunjukkan adanya gejala baru ke arah pemusnahan terhadap kelompok Ahmadiyah.
\end{abstract}

Kata kunci : prasangka, diskriminasi, komunikasi antarkelompok, stigma sesat, Ahmadiyah 


\section{PENDAHULUAN}

Sebagai negara dengan agama yang plural, dikotomi kelompok mayoritas-minoritas agama di Indonesia adalah sebuah realitas sosial yang tidak tertolak. Pluralitas aliran agama dan keanekaragaman ajaran agama menjadi warna tersendiri dalam realitas bangsa Indonesia yang memang bersifat heterogen. Konsekuensi dari kemajemukan adalah sensitivitas dalam kehidupan beragama yang pada suatu saat dapat saling mendekat, memperkuat, dan menyatu, tetapi pada saat yang lain mudah berpisah dan bahkan saling berbenturan satu sama lain. Prasangka dan diskriminasi menjadi bagian dari realitas sosial yang tak terelakkan dalam hubungan antarkelompok.

Kekerasan atas nama agama di Indonesia meningkat tajam pascareformasi politik 1998 seiring dengan menguatnya gerakan Islam radikal (Hamdi, 2012). Ahmadiyah sering menjadi subjek penganiayaan berulang yang dilakukan oleh Muslim Radikal. Jumlah serangan pada komunitas ini jauh melampaui serangan terhadap minoritas lainnya. Laporan Setara Institute menemukan bahwa dalam rentang waktu tiga tahun (2010-2012) kelompok Ahmadiyah dan Kristen merupakan korban terbanyak dari pelanggaran kebebasan beragama di Indonesia.

\section{Grafik 1}

Grafik Kekerasan Agama 2010--2012

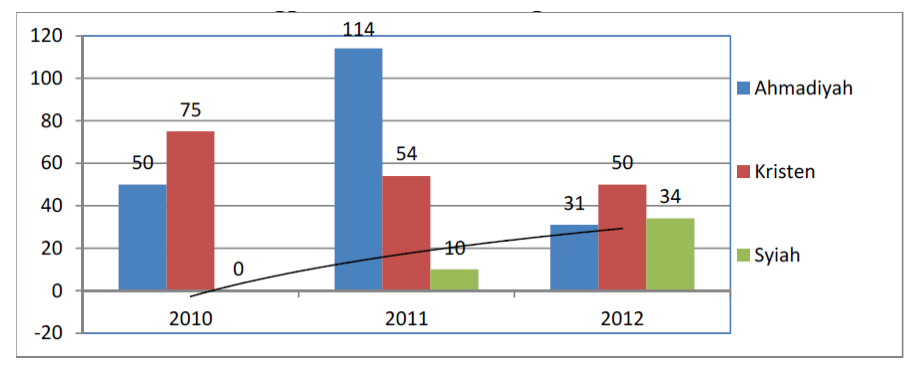

Sumber: INFID, 2013

Grafik 1 menunjukkan bahwa Ahmadiyah adalah kelompok dengan korban terbanyak dari pelanggaran kebebasan beragama di Indonesia. Berdasarkan data yang dihimpun INFID (2013), kekerasan terhadap Ahmadiyah telah terjadi berulang kali di berbagai daerah, termasuk Bogor, Banten, Bekasi, Tasikmalaya, dan Nusa Tenggara Barat. Pada tanggal 2 Mei 2012, masjid Al Mujahidin yang didirikan oleh jemaah Ahmadiyah di Kampung Babakansari, Tasikmalaya, Jawa Barat dibakar oleh massa yang tidak dikenal. Mimbar, sajadah, dan kitab suci telah berubah menjadi abu. Di Cikeusik, tiga pengikut Ahmadiyah 
kehilangan nyawa mereka dalam serangan terhadap komunitas mereka pada tanggal 6 Februari 2011.

Penelitian tentang Ahmadiyah sudah kerap dilakukan. Berbagai hasil penelitian tentang Ahmadiyah sering menyebutkan bahwa kasus Ahmadiyah merupakan klaim persaingan teologis antara kelompok fundamentalis dan Ahmadiyah (seperti Mas'ud, 2009; Setara Institute, 2010; dan ICG, 2008). Perspektif lain melihat konteks hukum yang tidak jelas dan kelalaian dari pemerintah terhadap hak asasi manusia (sebagai contoh Platzdasch, 2011; Colbran, 2010; Crouch, 2009; dan Budiwanti, 2009). Meski cukup sering dibicarakan, masalah di atas jarang sekali ditinjau dari aspek komunikasi, terutama dari sudut prasangka. Padahal, prasangka merupakan faktor penting untuk memahami penyebab terjadinya diskriminasi dan kekerasan terhadap Ahmadiyah.

Studi tentang prasangka utamanya dipandang dalam perspektif psikologi sosial. Penelitian yang dilakukan Johnson (1986) misalnya, menemukan bahwa munculnya prasangka disebabkan oleh hal tertentu, seperti (1) gambaran perbedaan antarkelompok, (2) nilai-nilai budaya yang dimiliki kelompok mayoritas sangat menguasai kelompok minoritas, (3) stereotip antaretnik, dan (4) kelompok etnik yang merasa superior, sehingga menjadikan etnik lain inferior. Penelitian lainnya menemukan sebab yang dapat memicu prasangka, antara lain deprivasi relatif (Davis, 1959), identitas (Tajfel \& Turner, 1979), orientasi dominasi sosial (Sidanius, et al., 1996), sifat otoriter (Altemeyer, 1981; serta Adorno, Frenkel-Brunswik, Levinson, \& Savvord, 1950), ancaman (Greenberg, Solomon, \& Pyszczynski, 1997), dan agama (Allport, 1954).

Meskipun sejumlah studi tersebut berfokus pada persoalan prasangka, studi tersebut kurang menekankan pada aspek ekspresi prasangka. Oleh karena itu, kajian ini melihat persoalan prasangka dan diskriminasi yang menimpa Ahmadiyah melalui perspektif komunikasi, khususnya ekspresi prasangka. Dalam konteks ini, konsep prasangka didefinisikan oleh Allport (1954) sebagai sikap antipati yang kaku (tidak toleran) terhadap sebuah kelompok orang tertentu. Prasangka dapat dirasakan saja atau diekspresikan, prasangka dapat ditujukan kepada kelompok keseluruhan atau individu sebagai anggota kelompok. Dalam ranah komunikasi, Samovar kemudian mengembangkan konsep prasangka dari Alport (1954), Menurutnya, prasangka diekspresikan dalam lima tahapan. Pertama, prasangka dapat dinyatakan melalui apa yang disebut sebagai antikolusi, yaitu istilah negatif atau stereotype mengenai 
anggota dari kelompok target. Kedua, prasangka dinyatakan melalui penghindaran diri atau menarik diri untuk berhubungan dengan kelompok yang tidak disukai. Ketiga, prasangka dinyatakan dalam bentuk prilaku yang menghasilkan diskriminasi. Keempat, prasangka berpindah ke level berikutnya, yaitu serangan fisik. Bentuk prasangka seperti ini akan meningkatkan permusuhan jika dibiarkan. Kelima, extermination (pembasmian), prasangka seperti ini akan mengarah pada tindakan pembunuhan massal, pembantaian, dan pemusnahan suatu suku bangsa seperti "penyucian etnis" di Serbia merupakan salah satu contoh dalam tahap ini.

Bagaimana dengan kekerasan yang terjadi terhadap Ahmadiyah di Indonesia? Penulis berasumsi bahwa kekerasan terhadap Ahmadiyah di Indonesia, merupakan akibat prasangka yang terbangun akibat stigmatisasi terhadap Ahmadiyah melalui penetapan hukum, peraturan, dan norma oleh institusi dan organisasi masyarakat dominan. Hal ini kemudian mengakibatkan terjadinya pelanggengan prasangka terhadap Ahmadiyah, sehingga kekerasan yang menimpa Ahmadiyah merupakan suatu hal yang tidak dapat dihindari. Dalam ranah komunikasi, tulisan ini menyajikan dua persoalan mendasar yang terjadi pada kelompok Ahmadiyah di Indonesia. Pertama, proses stigmatisasi terhadap
Ahmadiyah. Kedua, mengungkap kekerasan yang terjadi terhadap Ahmadiyah dengan pendekatan konsep ekspresi prasangka dari Samovar (2013).

Tulisan ini merupakan hasil desk research tentang kelompok minoritas Ahmadiyah di Indonesia. Dalam studi ini, upaya pengumpulan data dilakukan melalui pemantauan terhadap pemberitaan media nasional maupun lokal, cetak maupun elektronik, termasuk di dalamnya media-media online yang membahas peristiwa-peristiwa keagamaan di berbagai wilayah di Indonesia, dokumen-dokumen yang terkait dengan Ahmadiyah, dan dokumentasi video yang sempat diunggah ke publik. Selain itu, tulisan ini juga menggunakan berbagai laporan konflik terkait agama, berbagai peraturan pemerintah yang terkait dengan tema ini, dan studi-studi terkait. Analisis data dilakukan dengan menggunakan pendekatan kualitatif dengan fokus pada kasus-kasus kekerasan terhadap Ahmadiyah. Analisis dan interpretasi data menekankan pada upaya peneliti mengkaji dan memahami makna dan berbagai hal di balik yang teramati.

Menurutnya, prasangka diekspresikan dalam lima tahapan. Pertama, prasangka dapat dinyatakan melalui apa yang disebut sebagai antikolusi, yaitu istilah negatif atau stereotype mengenai anggota dari kelompok target. Kedua, prasangka dinyatakan melalui penghindaran diri 
atau menarik diri untuk berhubungan dengan kelompok yang tidak disukai. Ketiga, prasangka dinyatakan dalam bentuk prilaku yang menghasilkan diskriminasi. Keempat, prasangka berpindah ke level berikutnya, yaitu serangan fisik. Bentuk prasangka seperti ini akan meningkatkan permusuhan jika dibiarkan. Kelima, extermination (pembasmian), prasangka seperti ini akan mengarah pada tindakan pembunuhan massal, pembantaian, dan pemusnahan suatu suku bangsa seperti "penyucian etnis" di Serbia merupakan salah satu contoh dalam tahap ini.

\section{Stereotyping Ahmadiyah : menyoal fatwa MUI sesat Ahmadiyah}

Ahmadiyah sudah berkembang di Indonesia mulai awal abad XX. Kegiatan Ahmadiyah menyebar di berbagai daerah, seperti Yogyakarta, Bogor, Tasikmalaya, Sukabumi, Banjarnegara, Wonosobo, Kuningan, Lombok Timur, Purwokerta, dan daerah lainnya (Zulkarnaen, 2005). Ahmadiyah terbagi ke dalam dua kelompok, yaitu Ahmadiyah Qadian dan Ahmadiyah Lahore. Pengikut kelompok Qadian di Indonesia membentuk organisasi bernama Jemaat Ahmadiyah Indonesia (JAI) yang telah berbadan hukum sejak tahun 1953 (SK Menteri Kehakiman RI No. JA 5/23/13 Tgl. 13-3-1953). Sementara itu, pengikut kelompok Lahore membentuk organisasi bernama Gerakan Ahmadiyah
Indonesia (GAI) yang mendapat badan hukum nomor IX tanggal 30 April 1930 (Mahally, 2006).

Meskipun Ahmadiyah bukanlah sebuah kelompok keagamaan yang baru di Indonesia, keberadaannya seringkali ditolak oleh kelompokkelompok Islam lain (kelompok mainstream $)^{1}$. Majelis Ulama Indonesia(MUI) Ma'ruf Amin mengatakan Ahmadiyah adalah ajaran agama yang menyimpang serta sesat. Alasan utamanya yakni mengakui adanya nabi setelah Nabi Muhammad yakni Mirza Ghulam Ahmad. "Ahmadiyah itu merupakan kelompok menganut paham menyimpang, mengakui nabi setelah nabi Muhammad SAW," ujar Ma'ruf saat rapat dengan Komisi VIII DPR, Kamis(17/2/2011) malam. (Tribunnews, 2005) http://www.tribunnews.com/nasional

${ }^{1}$ Di Indonesia, kelompok Islam mainstream (arus utama Islam) mengarah pada kelompok-kelompok Islam yang dianut oleh sebagian besar masyarakat Islam serta dijadikan referensi dalam berbagai urusan yang berhubungan dengan hukum-hukum dalam kasus umat Islam di Indonesia masa kini, dalam istilah Martin van Bruinessen (1992), kelompokkelompok yang disebut kelompok Islam Mainstream atau ortodoksi diwakili oleh Majelis Ulama Indonesia (MUI), termasuk juga organisasi-organisasi kemasyarakatan yang ada di dalamnya. la menambahkan bahwa Ahlus Sunnah wal Jama'ah merupakan 'mainstream' Islam yang ortodoks, sedangkan yang menyimpang darinya adalah sempalan dan sesat. 
/2011/02/18/inilah-alasan-mui-

nyatakan-ahmadiyah-sesat

Wacana penyesatan terhadap Ahmadiyah sudah ada sejak tahun 1980, ketika Majelis Ulama Indonesia $(\mathrm{MUI})^{2}$ mengeluarkan

2 Pewacanaan aliran sesat oleh MUI bukan hal baru di Indonesia. Bahkan tiga tahun setelah pendiriannya, tepatnya pada 1978 , MUI sudah mulai mengeluarkan fatwa sesat pertama yang ditujukan kepada Jama'ah Muslimin Hizbullah. Setidaknya ada sekitar 14 aliran sesat, dan bahkan lebih, yang sudah diidentifikasi oleh MUI, antara lain: Jama'ah Muslimin Hizbullah, Ahmadiyah Qadiyan, Syi'ah, Darul Arqam, Islam Jama'ah, al-Qiyādah Islāmiyah, kelompok inkar al-sunnah, dan lain-lain. Menurut MUI. Sebuah aliran keagamaan bisa dikatakan sesat apabila memenuhi sepuluh kreteria5 Pertama, mengingkari salah satu dari enam rukun iman dan juga rukun Islam yang lima; Kedua, meyakini atau mengikuti akidah yang tidak sesuai dengan dalil syar'i (dalil yang secara eksplisit tercantum di dalam al-Qur'an dan Sunnah); Ketiga, meyakini turunnya wahyu setelah al-Qur'an; Keempat, mengingkari otentisitas dan atau kebenaran isi alQur'an; Kelima, melakukan penafsiran alQur'an yang tidak berdasar pada kaidahkaidah tafsir; Keenam, mengingkari kedudukan hadis Nabi sebagai sumber ajaran Islam; Ketujuh, menghina, melecehkan dan atau merendahkan para nabi dan rasul; Kedelapan, mengingkari Nabi Muhammad sebagai Nabi dan Rasul terakhir; Kesembilan, merubah, menambah dan atau mengurangi pokokpokok ibadah yang telah ditetapkan oleh syari'ah, seperti naik haji tidak ke Baitullah, shalat wajib tidak lima waktu; Kesepuluh, mengkafirkan sesama Muslim tanpa dalil syar'i seperti mengkafirkan Muslim hanya karena bukan kelompoknya. Lebih lanjut baca: MUI, Mengawal Aqidah Umat: Fatwa MUI tentang Aliran-aliran Sesat di fatwa yang menyesatkan Ahmadiyah Qadian. Fatwa MUI ini3 dikeluarkan setelah dua tahun sebelumnya (1978) Arab Saudi dan Robithah Alam Islamiy mengeluarkan fatwa sesat terhadap Ahmadiyah.

Pada masa kekuasaan Orde Baru, fatwa tersebut tidak menimbulkan polemik yang meluas di kalangan kelompok Islam, namun menjadi bermasalah ketika tahun 2005 MUI kembali menguatkan fatwa yang lebih keras dan menghakimi Ahmadiyah sebagai bukan bagian dari Islam. Berbeda dengan fatwa MUI 1980 yang hanya menyebutkan sesatnya aliran Ahmadiyah Qadian, fatwa MUI 2005 juga menyesatkan aliran Ahmadiyah Lahore. Dan berbeda dengan fatwa MUI 1980 yang tidak terlalu menimbulkan aksi kekerasan di masyarakat, fatwa MUI 2005

Indonesia (Jakarta: Sekretariat Majelis Ulama Indonesia).

3 Fatwa yang ditetapkan pada 28 Juli 2005 ini berisi tiga butir yaitu (1) Menegaskan kembali keputusan fatwa MUI dalam Munas II Tahun 1980 yang menetapkan bahwa Aliran Ahmadiyah berada di luar Islam, sesat dan menyesatkan, serta orang Islam yang mengikutinya adalah murtad (keluar dari Islam); (2) Bagi mereka yang terlanjur mengikuti Aliran Ahmadiyah supaya segera kembali kepada ajaran Islam yang haq (al-ruju' ila al-haqq), yang sejalan dengan al-Qur'an dan al-Hadis; (3) Pemerintah berkewajiban untuk melarang penyebaran faham Ahmadiyah di seluruh Indonesia dan membekukan organisasi serta menutup semua tempat kegiatannya. 
kemudian acap disambut dengan pelbagai macam aksi kekerasan terhadap Ahmadiyah yang terjadi di banyak daerah pascakeluarnya fatwa tersebut (Hasani \& Naipospos, 2011).

Dukungan yang dilakukan oleh kelompok anti-Ahmadiyah yang berasal dari kalangan organisasi Islam radikal seperti Front Pembela Islam (FPI), Forum Umat Islam (FUI), dan Hizbut Tahrir Indonesia semakin memperkuat fatwa "sesat" tersebut (Hasani \&Naipospos 2010). Sebuah klaim kebenaran yang diajukan kelompok dominan kemudian di blow-up media menjadi satu opini yang dapat mengarahkan opini publik ke dalam satu common sense yang dibentuk oleh kekuatan dominasi kelompok mayoritasdominan.

Realitas stigma sesat dan menyesatkan Ahmadiyah saat ini memang sulit dipungkiri oleh siapapun. Hampir semua elemen masyarakat familiar dengan istilah Ahmadiyah, mulai dari para elite pemerintahan, politikus, aktivis hingga masyarakat biasa yang ada di pedalaman. Namun, sangat disayangkan, ketenaran Ahmadiyah bersifat negatif. Karena mereka dikenal sebagai kelompok sesat dan menyesatkan. Banyak hal yang menyebabkan terjadinya hal ini. Salah satunya adalah sikap ormasormas Islam yang ramai-ramai menyesatkan pengikut Mirza Ghulam Ahmad ini. Begitu juga dengan sikap para elite pemerintahan (mulai dari pusat hingga daerah) yang tidak mau "mengambil risiko" di tengah derasnya aksi penentangan dan tuntutan pembubaran terhadap Ahmadiyah. Hingga para pemimpin daerah banyak yang mengeluarkan peraturan daerah (Perda) yang melarang aktivitas Ahmadiyah.

\section{Menilik ekpresi Prasangka terhadap Ahmadiyah}

Fatwa-fatwa MUI tentang tentang beberapa aliran keagamaan yang dianggap sesat disinyalir menimbulkan beberapa reaksi keras masyarakat terhadap aliran yang dianggap sesat tersebut. Selain itu, lembaga fatwa semi resmi ini juga dianggap turut bertanggung jawab atas terjadinya pengusiran dan aksiaksi kekerasan terhadap warga Ahmadiyah dan belakangan juga merambat ke kelompok Syiah dari masjid dan kampung mereka oleh ormas-ormas Islam garis keras seperti Front Pembela Islam (FPI) dan Forum Umat Islam (FUI). 1 Amir Ahmadiyah, Abdul Basit, dalam kesempatan Rapat Dengar Pendapat Umum dengan Komisi VIII, 12 Februari 2011, menyatakan bahwa sejak fatwa dikeluarkan oleh MUI, kekerasan terhadap Ahmadiyah meningkat. 2 Situasi ini terutama dia bandingkan dengan masa ketika Presiden Soeharto masih berkuasa, meskipun Ahmadiyah difatwakan MUI menyimpang, namun jamaah kelompok ini tidak dikenai tindakan- 
tindakan kekerasan oleh masyarakat mayoritas Islam.

Stigma sesat pada Ahmadiyah yang ditanamkan kepada publik menjadi penyebab timbulnya prasangka. Label sesat terhadap Ahmadiyah adalah sebuah hasil dari proses adanya prasangka. Prasangka (prejudice) dan pelabelan (stereotype) tidak dapat dipisahkan keterkaitannya. Prasangka mengawali adanya stereotype. Prasangka negatif meminimalkan kesempatan kontak dengan orang dari kelompok yang tidak disukai. Bila hal ini berlangsung sangat intensif, maka orang yang berprasangka akan terlibat hal-hal diskriminatif terhadap kelompok yang tidak disukai. Ketika diskriminasi menggantikan komunikasi, maka ekspresi kemarahan dan kebencian yang jelas ataupun tersembunyi akan menghalangi suatu kelompok untuk memperoleh kesempatan yang merupakan hak semua orang (Samovar, 2013).

Kedua, prasangka dinyatakan melalui penghindaran diri atau menarik diri untuk berhubungan dengan kelompok yang tidak disukai pengucilan). Penelitian Saeful Bahri, salah seorang peneliti Depag, membuktikan bahwa bukan berarti Jemaat Ahmadiyah tidak mau menyatu dengan komunitas nonAhmadi. Sikap eksklusif itu justru berawal dari perlakuan tidak adil dan reaksi keras pihak-pihak non-
Ahmadi yang mengucilkan mereka dari masjid, menganggap mereka najis dan mencuci bekas tempat mereka shalat. Dalam hal ini, bukan Jemaat Ahmadiyah yang mengisolasi diri namun justru merekalah yang dikucilkan oleh pihak luar (www.icrp-online.org/wmview.php. ArtID)

Ketiga, prasangka dinyatakan dalam bentuk prilaku yang menghasilkan diskriminasi. Pascatragedi Cikeusik tahun 2011, hasil pantauan Setara Institute (2011) justru memperlihatkan terjadinya lonjakan diskriminasi terhadap Ahmadiyah. Salah satu bentuk tindakan diskriminasi yang menimpa Ahmadiyah ialah kebijakan diskriminatif, yaitu penerbitan peraturan daerah (perda). Ini adalah bentuk diskriminasi yang paling merata terjadi di wilayah-wilayah yang selama ini banyak terdapat pengikut Ahmadiyah. Produk hukum yang dihasilkan oleh pemerintah, misal Surat Keputusan Bersama (SKB) Tiga Menteri4, berimplikasi

\footnotetext{
4 SKB yang ditetapkan pada tanggal 9 Juni 2008 ini, berisi enam butir, yaitu (1) Memberi peringatan dan memerintahkan kepada warga masyarakat untuk tidak menceritakan, menganjurkan atau mengusahakan dukungan umum ??? melakukan penafsiran tentang suatu agama yang dianut di Indonesia atau melakukan kegiatan keagamaan yang menyerupai kegiatan keagamaan dari agama itu yang menyimpang dari pokokpokok ajaran agama itu; (2) Memberi peringatan dan memerintahkan kepada penganut, anggota, dan/atau anggota
} 
luas terhadap munculnya peraturanperaturan pemerintah daerah di tingkat daerah yang juga turut memproduksi beragam peraturan yang semakin meminggirkan Ahmadiyah. Lembaga Bantuan

pengurus Jamaah Ahmadiyah indonesia (JAI), sepanjang mengaku beragama Islam, untuk menghentikan; penyebaran penafsiran dan kegiatan yang menyimpang dari pokok-pokok ajaran agama Islam, yaitu penyebaran paham yang mengakui adanya nabi dengan segala ajarannya setelah nabi muhammad saw.; (3) Penganut, anggota, dan/atau anggota pengurus Jamaah Ahmadiyah Indonesia (JAI) yang tidak mengindahkan peringatan dan perintah sebagaimana dimaksud pada diktum kesatu dan diktum kedua dapat dikenai sanksi sesuai dengan ketentuan peraturan perundang-undangan, termasuk organisasi dan badan hukumnya; (4) Memberi peringatan dan memerintahkan kepada warga masyarakat untuk menjaga dan memelihara kerukunan umat beragama serta ketenteraman dan ketertiban kehidupan bermasyarakat dengan tidak melakukan perbuatan dan/atau tindakan melawan hukum terhadap penganut, anggota, dan/atau anggota pengurus Jamaah Ahmadiyah Indonesia (JAI); (5) Warga masyarakat yang tidak mengindahkan peringatan dan perintah sebagaimana dimaksud pada diktum kesatu dan diktum keempat dapat dikenai sanksi sesuai dengan ketentuan peraturan Perundangundangan; (6) Memerintahkan kepada aparat pemerintah dan pemerintah daerah untuk melakukan langkah-langkah pembinaan dalam rangka pengamanan dan pengawasan pelaksanaan keputusan bersama ini; (7) Keputusan bersama ini berlaku sejak tanggal ditetapkan.
Hukum (LBH) Jakarta, misalnya, telah menemukan bahwa lima provinsi dan 33 kota telah mengeluarkan kebijakan yang melarang Ahmadiyah untuk mempraktikkan agama mereka. Larangan ini kemudian digunakan untuk melegitimasi berbagai bentuk serangan terhadap Ahmadiyah (INFID, 2013)

Penerbitan SKB Ahmadiyah dan berbagai peraturan yang menjadi turunannya menunjukkan bagaimana aktor negara turut berperan dalam melanggengkan prasangka negatif terhadap Ahmadiyah. Negara mengambil posisi sebagai "polisi moral" sehingga secara tidak langsung telah mendorong munculnya berbagai kelompok keagamaan yang juga memposisikan dirinya sebagai "polisi moral" atau "kelompok-kelompok kebenaran" yang kerap melakukan berbagai bentuk "penghakiman" terhadap kelompok-kelompok lain (Naipospos dkk., 2007; Gaus, 2008). Seperti yang ditunjukkan oleh Maliki (2010), aliran-aliran mainstream di Indonesia mampu mendominasi frame beragama umat Islam, tidak hanya dalam segi ritualitas, tetapi juga dalam sikap yang secara bersamaan terpolarisasi ke dalam arus mainstream. Preference umat juga akan selalu berkiblat pada mainstream, termasuk produk hukum.

$$
\text { Beberapa studi (misal }
$$
Muqoyyidin, 2012; Asfinawati dkk., 
2008; ICG 2008), memperlihatkan bagaimana elemen radikal, yang tidak banyak mendapat dukungan politik di Indonesia, telah mampu membangun kontak di dalam pemerintah dan menggunakan teknik standar advokasi masyarakat sipil untuk mempengaruhi kebijakan pemerintah. Dalam hal ini, organisasi yang tidak toleran terhadap Ahmadiyah bekerja melalui infiltrasi MUI dan juga memperluas dukungan tokoh Islam dan organisasi masyarakat nonradikal yang lain. Infiltrasi dan aliansi ini, mereka lakukan untuk menggalang dukungan dalam mendesak negara untuk mengeluarkan kebijakan yang tidak toleran terhadap keberadaan Ahmadiyah, dari mulai kebijakan di tingkat nasional hingga daerah. Dalam hal ini, prasangka terhadap Ahmadiyah, dilanggengkan melalui sejumlah kebijakan yang ditujukan kepada mereka. Hal ini sejalan dengan apa yang dikemukakan Samovar (2013):

"Banyak prasangka dibangun oleh organisasi dan institusi masyarakat yang besar. Organisasi-organisasi ini menetapkan hukum, peraturan, dan norma yang dapat menimbulkan prasangka dalam masyarakat. Hukum dan peraturan ini menolong untuk mempertahankan kekuasaan suatu kelompok dominan terhadap kelompok di bawahnya."
Serangkaian kebijakan dan peraturan dijadikan legitimasi oleh kelompok mayoritas untuk meminggirkan kelompok minoritas. Bahkan, implementasi peraturan tersebut justru lebih diskriminatif. Organisasi masyarakat yang menolak hidup bersama Ahmadiyah mendorong pemerintah untuk membuat peraturan yang diskriminatif, kemudian menggunakan peraturan tersebut sebagai dasar tindakan kekerasan mereka (Kontras 2014; Cholil dkk., 2013; Naipospos et.al., 2013; dan Azhari, Rumadi, \& Nisa 2012).

Berbagai bentuk tindakan diskriminasi lainnya yang menimpa Ahmdiyah di Indonesia (Hasani \& Naipospos, 2011) antara lain adalah pemaksaan pindah keyakinan dan diskriminasi layanan kependudukan. Tindakan diskriminatif dalam bentuk pemaksaan pindah keyakinan/ pertaubatan paksa adalah bentuk kedua diskriminasi lanjutan terhadap Ahmadiyah. Di daerah Tasikmalaya, contohnya, kerap terjadi pertaubatan secara paksa. Enam anggota JAI Tasikmalaya dikabarkan ditaubatkan. Pertaubatan tersebut dilakukan di Mesjid Agung Tasikmalaya yang dipimpin Ketua DPD FPI Jabar, Abdul Kahar, Selasa, 12 Juli 2011. Kahar menyatakan anggota JAI tersebut bertaubat tidak dalam tekanan. Habib Riziq Shihab yang turut hadir dalam acara itu memberikan pernyataan bahwa hingga saat ini sudah 324 jemaat 
Ahmadiyah kembali ke Islam dan 4.170 masih menganut Ahmadiyah.

Layanan kependudukan juga merupakan bentuk lain diskriminasi yang menimpa Ahmadiyah. Mereka sulit mendapatkan pelayanan surat nikah dan pemberian Kartu Tanda Penduduk (KTP). Pengawas Aliran Kepercayaan Masyarakat (Pakem) Kuningan, contohnya, pernah mengeluarkan Surat Keputusan yang ditujukan kepada pemerintahan kecamatan dan Kantor Kementerian Agama (Kemenag) Kuningan untuk tidak mengeluarkan KTP dan tidak menikahkan para Jemaat Ahmadiyah Indonesia (Hasani \& Naipospos, 2011)

Keempat, prasangka berpindah ke level berikutnya, yaitu serangan fisik. Bentuk prasangka seperti ini akan meningkatkan permusuhan jika dibiarkan. Peristiwa penyerangan dan pengusiran terhadap Ahmadiyah di Ketapang, Cikeusik (2011), pengusiran Ahmadiyah di Bangka (2016) dan peristiwa-peristiwa lainnya yang menimpa Ahmadiyah di Indonesia, memberikan gambaran kobaran kebencian karena perbedaan pandangan yang menimbulkan kekerasan terhadap kelompok tersebut. Fatwa sesat dan SKB Ahmadiyah memicu munculnya kekerasan yang dialami oleh kelompok tersebut di berbagai wilayah di Indonesia, bahkan dengan SKB itu, kekerasan yang dilakukan oleh kelompok islam radikal seperti mendapat pembenaran legal
(Subakir, 2010). Kelompokkelompok radikal mengambil fatwa ini untuk menyerang institusiinstitusi Ahmadiyah di Jawa Barat, Lombok Timur, dan beberapa daerah lain di Indonesia; puluhan mesjid Ahmadiyah ditutup dan rumahrumah penganut Ahmadiyah dihancurkan (HRW 2013; ICG 2008). Berbagai fakta tentang peristiwa penyerangan dan pengusiran terhadap Ahmadiyah menunjukkan bahwa prasangka terhadap kelompok ini, tidak lagi berada dalam tahapan diskriminasi, namun prasangka telah diekspresikan melalui kekerasan fisik, dalam skema ekspresi prasangka Samovar (2013), kekerasan fisik, merupakan tingkatan yang lebih tinggi dari diskriminasi, bahkan jika dibiarkan, akan menuju pada tindakan pemusnahan (extermination) pada kelompok tersebut.

Berbagai media maupun laporan tentang kebebasan beragama menyebutkan bahwa kasus penyerangan terhadap Ahmadiyah memang telah lama terjadi. Di Lombok Timur, massa dengan beringas membakar pemukiman warga Ahmadiyah pada tanggal 1013 September 2002. Di Praya, Lombok Tengah, warga Ahmadiyah mengungsi ke Markas Kepolisian Resor (Mapolres) setempat setelah massa menyerbu mereka pada 17 Maret 2006. Sebulan sebelumnya tepatnya 4 Februari 2006 kasus serupa terjadi di Desa Lingsar, 
Lombok Barat. Pada awal tahun 2011 tercatat kekerasan terhadap warga Ahmadiyah terjadi di Makasar, dan di Cikeusik, Pandeglang, Banten yang mengakibatkan tiga warga Ahmadiyah meninggal dunia dan sejumlah orang luka-luka. Kasus yang terbaru adalah penyegelan masjid Ahmadiyah di Bukit Duri Jakarta-Selatan pada bulan Juli 2015 dan juga pengusiran Ahmadiyah di Kelurahan Sri Menanti, Kecamatan Sungailiat, Kabupaten Bangka, pada $5 \quad$ Februari 2016 (https://m.tempo.co/read/news/2016/ 02/05/058742660/diusir-jemaahahmadiyah-bangka-dievakuasi-ketempat-rahasia, diakses pada 31 Maret 2016)

Insiden Cikeusik, misalnya, memperlihatkan kualitas eskalasi kekerasan baru berupa pembunuhan secara sewenang-wenang. Fakta peristiwa ini juga menunjukkan bahwa serangan sangat terorganisasi dan telah direncanakan sejak jauh hari, terlihat dari sistem penggunaan pita di atas. Penandaan ini dapat dilihat sebagai bentuk pembagian kerja, sistem koordinasi dan komando. Penandaan ini tidak sekadar pembeda antara Jamaah Ahmadiyah dengan pihak penyerang. Pihak penyerang membakar mobil, merusak motor dan rumah (CRCS, 2010).

Meskipun tidak banyak terdengar di media massa, warga Ahmadiyah yang mengungsi di
Wisma Transito, Mataram, Nusa Tenggara Barat mengalami masalah yang paling serius dan bahkan situasinya terus memburuk. Pada bulan Februari 2006 sekitar 136 keluarga mengungsi ke tempat itu karena rumah-rumah mereka dihancurkan oleh kelompok dan warga Muslim lain di Ketapang. Pada Januari 2009 Pemerintah Daerah Nusa Tenggara Barat (Pemda NTB) menghentikan bantuan makanan ke pengungsi Ahmadiyah yang berjumlah sekitar 36 Kepala Keluarga (KK). Tempat pengungsian juga sangat memprihatinkan. Satu ruang dihuni banyak keluarga dan hanya disekat kain. Pada tahun 2010 sekitar 33 keluarga yang terdiri dari 126 orang masih bertahan tinggal di pengungsian. Selain kemiskinan dan keterbatasan fasilitas hidup seharihari di pengungsian, masalah lain yang mulai terlihat jelas bagi para pengungsi warga Ahmadiyah adalah pelanggaran hak-hak sipil mereka oleh birokrasi pemerintah. Hulu dari tidak terpenuhinya hak-hak sipil warga Ahmadiyah adalah tidak dipenuhinya hak untuk memperoleh KTP (baru) bagi para pengungsi warga Ahmadiyah. Nasib pengungsi di Mataram kini nyaris diingkari keberadaannya sebagai warga negara karena kehilangan hak sosial-politik dan ekonominya. Salah satu muaranya adalah kesulitan memperoleh atau memperbaharui KTP (CRCS, 2010) 
Adanya fakta-fakta peristiwa serangan kekerasan terhadap Jamaah Ahmadiyah di berbagai wilayah di Indonesia menunjukkan bagaimana prasangka telah mengarah pada tindakan kekerasan fisik terhadap kelompok ini. Fakta-fakta seperti pengusiran terhadap komunitas Ahmadiyah di Ketapang dan Bangka, penyerangan dan penganiayaan terhadap komunitas Ahmadiyah di Cikeusik, dan berbagai wilayah di Indonesia memperlihatkan bahwa eskalasi kekerasan yang menimpa Ahmadiyah mengarah pada apa ditunjukkan dalam elemen-elemen kejahatan genosida. Istilah "membunuh" dalam poin (a) UU No. 26 tahun 2000 adalah istilah yang dapat digunakan secara bergantian dengan istilah "menyebabkan kematian" (insiden Cikeusik). Selain itu, peristiwa yang menimpa kaum perempuan Ahmadiyah di Desa Ciparay, Kecamatan Cibeber dan di Kampung Neglasari Desa Sukadana Kecamatan Campaka (Komnas Perempuan, 2008), mereka mengalami kekerasan seksual dan ancaman kekerasan pada saat penyerangan yang mengakibatkan penderitaan fisik atau mental berat (point b UU No. 26 tahun 2000).

Berbagai peristiwa tersebut, jika dibiarkan akan mengarah pada peristiwa yang lebih ekstrim (pembantaian dan pemusnahan kelompok) seperti yang dialami Ahmadiyah di berbagai negara. Meskipun sejumlah studi menunjukkan peran polisi dalam menangani konflik-konflik tersebut belum memadai (ICG, 2012), ada bukti yang menunjukkan sebenarnya polisi sebagai aparat negara berhasil meredam gejolak penolakan, seperti yang terlihat di Manis Lor dan Kebayoran Lama (Kontras, 2012). Dengan demikian, peran polisi sebagai aparat negara sangat penting dalam meredam kekerasan terhadap Ahmadiyah. Di tengah segala keterbatasannya, tindakan tegas aparat negara tersebut cukup berhasil meredam konflik. Perusakan dan penganiayaan yang sebelumnya kerap terjadi seketika berhenti. Selain mengerahkan kekuatan, polisi melakukan tindakan pencegahan dengan mempersuasi pihak-pihak yang berkonflik. Kontras melaporkan bahwa Nur Rohim, Sekretaris JAI Manis Lor, beberapa kali didatangi aparat kepolisian yang meminta pihaknya agar menghindari bentrokan (Kontras, 2012, Panggabean dan Ali-Fauzi, 2014).

\section{Dapatkah Komunikasi Berperan?}

Dalam konteks komunikasi, adanya tindak kekerasan atas nama agama adalah bukti bahwa ada kemacetan komunikasi antarberbagai golongan dalam masyarakat kita yang majemuk. Jika demikian, dapatkah komunikasi berperan? Komunikasi memang bukan panasea untuk menyelesaikan berbagai masalah. Jika diakui bahwa komunikasi adalah bagian dari 
proses budaya yang beradab, maka komunikasi dengan berbagai kiat dan pendekatannya bisa dipercaya untuk berperan meredam atau paling sedikit mengantisipasi datangnya konflik (Mulyana, 2005; Hamidjoyo, 2001).

Terjadinya

kegagalan

komunikasi antarkelompok yang berbeda disebabkan oleh penekanan pada "kesamaan" dan bukan “perbedaan” (Devito,1997: 488). Pengabaian terhadap perbedaan menjadi sumber utama terjadinya kekerasan terhadap Ahmadiyah. Relasi antara Kelompok Islam Mainstream dan Ahmadiyah, secara kasat mata yang terlihat adalah konsep 'atas nama mayoritas'. Dalam kasus Ahmadiyah di atas, kerap kali kebijakan dipakai untuk mengukuhkan hegemoni satu kelompok kecil yang ada dalam payung besar mayoritas. Kelompok ini bisa saja menciptakan suatu model definitif terhadap apa yang diyakini sebagai "yang benar" oleh agama. Seperti dikemukakan Rubent dan Stewart (2013: 383), penilaian terhadap kelompok lain dilakukan secara tidak sadar karena kelompok menggunakan nilai dan kebiasaan sendiri sebagai kriteria untuk segala penilaian. Kita cenderung menganggap praktik-praktik budaya sendiri adalah benar; dan budaya yang sebaliknya seringkali dianggap 'salah' daripada 'berbeda'. Dalam kondisi yang demikian, suatu kelompok cenderung membenarkan kelompknya dan mengabaikan kelompok lain.

Terkait dengan hal tersebut, Pettigrew (dalam Baron \& Byrne, 2004) menyatakan bahwa meningkatkan kontak antara orang yang berasal dari kelompok yang berbeda dapat mengembangkan pemahaman akan kesamaan di antara mereka; (2) walaupun stereotip sulit untuk berubah, stereotip dapat digeser bila terdapat sejumlah informasi yang tidak konsisten dengan stereotip yang diberikan tersebut atau ketika individu menemukan sejumlah pengecualian yang cukup terhadap stereotip yang dimilikinya; (3) meningkatkan kontak juga dapat membantu melawan ilusi homogenitas outgroup.

Meskipun ada perbedaan antara berbagai kelompok kepentingan, selama masih terbuka saluran komunikasi, masih ada kemungkinan untuk mencapai saling pengertian, akomodasi, mungkin malah kesepakatan kerja sama dan perdamaian. Oleh karena itu, dialog, musyawarah, perlu dilembagakan, dibudayakan. Komunikasi bukan propaganda, penyebaran tak berimbang dari pendapat atau kemauan dari yang kuat kepada yang lemah. Namun, komunikasi adalah proses penciptaan kebersamaan dalam makna. Intinya adalah mencari titik temu; modalitasnya adalah musyawarah, dialog, negosiasi; tujuannya untuk mencapai 
kesepakatan untuk mendekatkan kepentingan pihak-pihak yang berkepentingan (win-win). Musyawarah bukan teknik atau taktik pengambilan keputusan, melainkan 'semangat' (spirit) memahami dan menghormati pendapat orang lain, yang 'menjiwai' (inspire) proses pengambilan keputusan. Musyawarah tidak berkonotasi 'kuno' atau 'modern', sebab dalam masyarakat yang modern pun dihidupkan prinsip dialog, deliberation, give and take, accomodation. Tujuannya adalah mencapai kesepakatan bersama untuk menghindari konflik (Hamidjoyo, 2001).

Publikasi media juga merupakan faktor lain yang turut berperan dalam eskalasi kekerasan terhadap Ahmadiyah. Hal ini menyebabkan dampak yang ditimbulkannya menjadi berantai. Peran media dalam mengawal pengungkapan kasus mulai proses penyidikan hingga persidangan kasus-ksus publik, dengan porsi yang cukup besar melalui pemberitaan, analisis hingga sajin investigasi, menjadikan setia proses hukum yang sedang berlangsung berada dalam pantauan dan kontrol publik secara langsung. Akibatnya, fakta apapun yang tersaji langsung terkonstruksi ke dalam ingatan publik dan menjadi fakta tersendiri yang melahirkan berbagai spekulasi. Media memiliki pengaruh yang kuat dalam mengkonstruksi perspesi khalayak mengenai realitas sosial. Dalam kasus ini, media massa lebih tepat dipandang sebagai pihak yang melakukan pendefinisian terhadap realitas sosial (McQuail, 2010; Baran \& Davis, 2009). Artinya, media merupakan kekuatankekuatan yang melakukan mediasi yang pada saat melaporkan berbagai kejadian secara otomatis mengemukakan berbagai cara pandang tertentu sebagai hasil dari interpretasi terhadap kejadiankejadian itu. Media pada proses berikutnya bisa membentuk dan melakukan penstrukturan terhadap kesadaran kita yang memiliki konsekuensi secara sosial maupun politis.

Media massa harus memahami fakta kemajemukan aliran dan sekte di masyarakat dan menjalankan profesinya sesuai dengan pemahaman tersebut. Penggunaan label yang mencerminkan penilaian dan partikularisme keagamaan, seperti "aliran sesat", harus dihindari. Gagasan dan inisiatif di bidang pengelolaan dan transformasi konflik perlu dikedepankan kepada pembaca, dari mana pun sumbernya. Media perlu mengambil sikap yang secara sadar dan langsung mengangkat agenda rekonsiliasi dan resolusi konflik sebagai prioritas peliputan konflik sektarian. Pembaca juga tertarik dengan berita dan liputan rekonsiliasi dalam konflik sektarian. 
SIMPULAN

Adanya fakta-fakta peristiwa serangan kekerasan terhadap Jamaah Ahmadiyah di berbagai wilayah di Indonesia mengarah pada gejala pembasmian (extermination). Eskalasi kekerasan terhadap kelompok-kelompok minoritas di Indonesia menunjukkan eskalasi yang serius. Kekerasan dan diskriminasi bukan hanya dilakukan oleh aktor-aktor nonnegara yang berujung pada kekerasan, tetapi juga dilegitimasi oleh negara melalui produk-produk hukum yang diskriminatif, terutama melalui peraturan daerah, dan dengan membiarkan setiap kekerasan yang menimpa kelompok-kelompok minoritas nyaris tidak terhukum.

Komunikasi dapat memerankan diri dalam meredam kekerasan melalui proses penciptaan kebersamaan dalam makna sehingga dapat menghilangkan prasangka antarkelompok. Intinya adalah mencari titik temu melalui musyawarah, dialog, negosiasi; tujuannya untuk mencapai kesepakatan untuk mendekatkan kepentingan pihak-pihak yang berkepentingan. Eksistensi Indonesia sebagai negara-bangsa sangat ditentukan oleh kesadaran dan semangat kemajemukan di kalangan segenap warganya. Indonesia tetap akan tegak selama semangat kemajemukan juga tegak. Demikian juga sebaliknya, Indonesia akan berakhir bersamaan dengan runtuhnya semangat kemajemukan. Menjadi keistimewaan tatkala semua kemajemukan yang ada bisa dipahami dan dikelola secara baik. Menjadi kerawanan tatkala kemajemukan yang ada tidak dipahami secara baik sehingga kemajemukan menjadi bom waktu yang bisa meletuskan konflik sosial di mana-mana. Inilah yang kerap terjadi belakangan dalam kehidupan berbangsa, terutama dalam menghadapi persoalan Ahmadiyah. Kemajemukan tak lagi dipahami sebagai identitas bangsa ini sehingga terjadi pelbagai macam aksi kerusuhan dan konflik sosial yang justru menyangkal adanya kemajemukan.

\section{DAFTAR PUSTAKA}

Adorno, T.W., Frenkel-Brunswik, E., Levinson, D.J., \& Sanford, R.M. (1950). The authoritarian personality. New York: Harper.

Altemeyer, B. (1981). ARight-wing Authoritarianism. Canada: University of Manitoba Press.

Asfinawati et al.. (2008). Kekerasan terhadap Jama'ah Ahmadiyah di Manislor Kuningan, Jawa Barat, dan Lombok, NTB; Kekerasan terhadap Jama'ah Al Qiyadah Al Islamiyah Siroj Jaziroh Padang, Sumatera Barat; Kekerasan terhadap Jemaat Gereja di Bandung, Jawa Barat. Jakarta : Lembaga 
Bantuan Hukum (LBH) dan Kontras.

Azhari, M. Subhi, Rumadi Ahmad, dan Nurun Nisa. (2012). Laporan Akhir Tahun Kebebasan Beragama dan Intoleransi 2012. Jakarta: The Wahid Institute.

Baron, R.E. \& Byrne, D. (2004). Psikologi Sosial, Ed. 10 Jilid 1. Alih Bahasa: Dra.Ratna Djuwita, Dipl. Psychl. et al. Jakarta: Erlangga.

Bagir, Z. A. (2011). Telaah kasus Ahmadiyah di Indonesia. Yogyakarta: CRCS-UGM.

Baran, Stanley J. Dennis K. Davis. (2009). Mass Communiction Theory: Foundations, Ferment, and Future. Fifth Edition. USA: Lyn Uhl

Budiwanti, Erni. (2009). Pluralism Collapse: A Study of Jamaáh Ahmadiyah Indonesia and its Persecution. Singapore: Asia Research Institute.

Cholil, Suhadi, Zainal Abidin Bagir, Moh. Iqbal Ahnaf, Marthen Tahun, Budi Ashari. (2013). Laporan Tahunan Kehidupan Beragama di Indonesia tahun 2012. Yogyakarta: Universitas Gadjah Mada.

Colbran, Nicola (2010). Realities and Challenges in Realising Freedom of Religion or Belief in Indonesia. The International Journal of Human Rights 14 (5), 678-704.
Center for Religious and Crosscultural Studies (CRCS). (2009). Laporan Tahunan Kehidupan Beragama Di Indonesia Tahun 2008. Yogyakarta: CRCS UGM

Crouch, Melissa. (2009). Implementing the Regulation on Places of Worship in Indonesia: New Problems, Local Politics and Court Action. Asian Studies Review 34 (4), 403-419.

Davis, J.A. (1959). Group decision and social interaction: a theory of social decision schemes. Psycholgical Review, 80, 7-25

Devito, Joseph A. (1997). Human Communication. HarperCollins Publisher. New York.

Ghanea, N. Are Religious Minorities Really Minorities?. Oxford Journal of Law and Religion 11 (2012), 57-79.

Gaus, Ahmad AF. (2008). Kebebasan Beragama dan Hakhak Minoritas. Makalah disampaikan dalam Workshop "Promosi Kebebasan Beragama dan Hak-Hak Minoritas untuk Integrasi Sosial yang Dilaksanakan Oleh CSRC UIN Syarif Hidayatullah Jakarta 3-7 November 2008

Greenberg, J. Solomon, S., Pyszczynski, T. (1997). Terror management theory of selfesteem and cultural worldviews: Empirical 
assessments and. Advances in experimental social psychology 29 (S 61): 139

Hamdi, Ahmad Zainul, 2012. Klaim Religious Authority dalam Konflik Sunni-Syi'i Sampang Madura. ISLAMICA. 6 (2)

Hamidjoyo, Santoso. 2001. Konflik Sosial dengan Tindak Kekerasan dan Peranan Komunikasi. Jurnal

Komunikasi Mediator 2 (1)

Hasani, Ismail dan Bonar Tigor Naipospos [ed]. 2010. Negara Menyangkal, Kondisi

Kebebasan

Beragama/Berkeyakinan di Indonesia 2010, Jakarta: Setara Institute.

Hasani, Ismail \& Bonar Tigor Naipospos. (2011). Ahmadiyah dan Keindonesiaan Kita. Jakarta: Pustaka Masyarakat Setara

Human Rights Watch (HRW). (2013). In Religion's Name: Abuses against Religious Minorities in Indonesia. New York: Human Rights Watch. International NGO Forum on Indonesian Development (INFID). (2013). Laporan Kebebasan Beragama di Indonesia 2010-2012. Jakarta: INFID.

International Crisis Group (ICG).

(2008). Indonesia: Implikasi SKB (Surat Keputusan Bersama) tentang Ahmadiyah. Brussels: ICG.
International Crisis Group (ICG) (2012). Indonesia: Akibat Fatal dari Pemolisian yang Lemah. Asia Report No. 218. Brussels: ICG.

Johnson. Allan G. (1986). Human Arrangements: an Introduction to Sociology, Sandigeo: Harcourt Brace Jovanovich Publishing.

Komnas Perempuan.(2008). Perempuan dan Anak Ahmadiyah: Korban Diskriminasi Berlapis. Jakarta: Laporan Pemantauan Kondisi HAM Perempuan Ahmadiyah

Kontras. (2011). Negara tak kunjung terusik: Laporan hak asasi manusia peristiwa penyerangan Jama'ah Ahmadiyah Cikeusik 6 Februari 2011. Jakarta: Kontras.

Kontras. (2012). Laporan Pemantauan Pemolisian \& Hak Berkeyakinan, Beragama dan Beribadah. Jakarta: Kontras.

Kontras. (2014). Pelanggaran HAM dan Pelanggaran HAM Berat Dalam Kasus-Kasus Kebebasan Beragama, Berkeyakinan dan Beribadah di Indonesia. Jakarta: Solidaritas Perempuan.

Lukmantoro, Triyono. (2011). Wacana Ahmadiyah di Media Massa (Analisis Wacana Pemberitaan Harian Surat Merdeka dalam Kasus 
Penyerangan terhadap Jemaat Ahmadiyah di Indonesia di Cikeusik, Pandeglang, Banten). Laporan Penelitian DIPA FISIP Universitas Diponegoro

Mahally, Abdul Halim (2006). Benarkah Ahmadiyah Sesat?. Jakarta: PT Cahaya Kirana Rajasa.

Maliki, Dewi Nurul. (2010). Resistensi Kelompok Minoritas Keagamaan Jemaat Ahmadiyah Indonesia. Jurnal Ilmu Sosial dan Politik, Volume 14 (1). Hlm 47-62

McLaughlin, Eugene., John Muncie (eds.). (2001). The Sage Dictionary of Criminology. New Delhi:Sage Publications

McQuail, Dennis A. (2010). Mcquail's Mass Communication Theory. $6^{\text {th }}$ ed. Sinagapore: SAGE Publications Asia-Pasific

Mulyana, Deddy. (2005). Ilmu Komunikasi Suatu Pengantar. Jakarta: PT Remaja Rosdakarya

Muqoyyidin, Andik. Wahyun. (2012). Potret Konflik Bernuansa Agama di Indonesia (Signifikansi Model Resolusi Berbasis Teologi Transformatif). Analisis, Volume XII, Nomor 2, h. 315340

Naipospos, Bonar Tigor, et al. (2013). Leadership without Initiative: The Condition of Freedom of Religion/Belief in
Indonesia 2012. Jakarta:

Pustaka Masyarakat Setara. Naipospos, Bonar Tigor, et al. (2007). Tunduk pada Penghakiman Massa:

Pembenaran Negara atas Persekusi Kebebasan Beragama dan Berkeyakinan. Jakarta: Setara Institute

Panggabean, Ihsan Ali-Fauzi. (2014). Pemolisian Konflik Keagamaan di Indonesia. Jakarta. Pusat Studi Agama dan Demokrasi (PUSAD) Paramadina

Platzdasch, Bernard. (2011). Religious Freedom in Indonesia: The Case of Ahmadiyah. ISEAS Working Paper: Politics and Security Series, No. 2

Rubent, Brent D., Lea P. Stewart. (2013). Komunikasi dan Perilaku Manusia. Edisi 5. Jakarta: PT. Raja Grafindo Persada

Samovar, Larry A.Richard E. Porter, Edwin R. McDaniel. (2013). Communication Between Culture. Salemba Humanika, Jakarta.

Setara Institute. (2010). Atas nama ketertiban dan keamanan: Persekusi Ahmadiyah di Bogor, Garut,Tasikmalaya, dan Kuningan. Jakarta: Setara Institute.

Sidanius, Jim, Pratto, Felicia, \& Bobo, Lawrence (1996), Racism, Conservatism, 


affirmative action, and
intelectual sophistication: a
matter of $\quad$ principled
conservatism or Group
dominance?, Jounal of
Personality and Social
Psychology. 20, 476-490

Subakir, Ahmad et al. (2010). Potret Buram Kebebasan Beragama. Yogyakarta: Nadi PustakaSTAIN Kediri Press.

Tajfel, H. \& Turner, J.C. (1979). An integrative theory of intregroup conflict. In W.G. Austin and S. Worchel (eds). The social psychology of intergroup relations (pp.33-47). Montley, CA: Brooks/Cole

Van Bruinessen, Martin. (1992). 'Gerakan Sempalan di

Kalangan Umat Islam

Indonesia: Latar Belakang

Sosial-Budaya.' Ulumul

Qur'an . Volume 3 (1), 17-32

Zulkarnaen, Iskandar. 2005. Gerakan

Ahmadiyah di Indonesia.

Yogyakarta: LkiS 